\title{
Opioid Overdose in Ohio: Comprehensive Analysis of Associated Socioeconomic Factors
}

Chihyun Park ${ }^{1}$, Sara Crawford ${ }^{1}$, Rocio Lopez ${ }^{1}$, Anna Seballos ${ }^{1}$, Jean R. Clemenceau ${ }^{1}$, Tyler Coy $^{1}$, Gowtham Atluri ${ }^{2}$, Tae Hyun Hwang ${ }^{1}$

1. Department of Quantitative Health Sciences (QHS), Lerner Research Institute, Cleveland Clinic, Cleveland, Ohio, USA

2. Department of Electrical Engineering and Computer Science (EECS), University of Cincinnati

Corresponding authors:

Gowtham Atluri, Dept. of EECS, University of Cincinnati, P.O. Box 210030, Cincinnati, OH 45221, USA; gowtham.atluri@uc.edu

Tae Hyun Hwang, PhD, Dept. of QHS, Lerner Research Institute, Cleveland Clinic, 9500 Euclid Ave, Cleveland, OH 44195, USA; (216)-442-5565; hwangt@ccf.org

Keywords: opioid, analgesics, analysis, regression, socioeconomic

Word count: 2584 


\begin{abstract}
Objective: Our study focused on identifying socioeconomic factors associated with death by opioid overdose in Ohio communities at the census tract level.
\end{abstract}

Materials and Methods: A large-scale vital statistic dataset from Ohio Department of Health $(\mathrm{ODH})$ and U.S. Census datasets were used to obtain opioid-related death rate and socioeconomic characteristics for all census tracts in Ohio. Regression analysis was performed to identify the relationships between socioeconomic factors of census tracts and the opioid-related death rate for both urban and rural tracts.

Results: In Ohio from 2010-2016, whites, males, and people aged 25-44 had the highest opioidrelated death rates. At the census tract level, higher death rates were associated with certain socioeconomic characteristics (e.g. percentage of the census tract population living in urban areas, percentage divorced/separated, percentage of vacant housing units). Predominately rural areas had a different population composition than urban areas, and death rates in rural areas exhibited fewer associations with socioeconomic characteristics.

Discussion: Predictive models of opioid-related death rates based on census tract-level characteristics held for urban areas more than rural ones, reflecting the recently observed ruralto- urban geographic shift in opioid-related deaths. Future research is needed to examine the geographic distribution of opioid abuse throughout Ohio and in other states.

Conclusion: Regression analysis identified associations between population characteristics and opioid-related death rates of Ohio census tracts. These analyses can help government officials and law official workers prevent, predict and combat opioid abuse at the community level. 


\section{INTRODUCTION}

Opioids have been widely used to control and mitigate chronic and postoperative pain.

According to data published in the Center for Disease Control and Prevention (CDC) Morbidity and Mortality Weekly Report in 2017, 130 people died each day from opioid-related drug overdoses.[1] In 2017, the U.S. Department of Health and Human Services declared the opioid epidemic a public health emergency.[2] Despite recommendations against the use of opioids, during the past two decades, sharp increases in opioid prescriptions have resulted in opioid abuse and accidental opioid overdoses. The rate of opioid prescriptions written has steadily decreased since 2010, but the rate of drug overdose deaths involving any opioid continues to increase.[3, 4] The increase of such opioid overdose deaths in 2016 was due to the use of heroin and synthetic opioids other than methadone (such as illicitly manufactured fentanyl).[3, 4] While the United States faces the most serious problems with opioid abuse and opioid-related deaths, opioid abuse is an international issue, such as the trafficking of opioid painkillers for non-medical use in

\section{Africa.[5]}

To address the continuing opioid crisis, it is necessary to identify the characteristics of patients who have used opioids over a long period of time and have died due to overdose. Several studies have aimed to reveal the association between socioeconomic factors and opioid-related mortality. Previous studies have revealed that poverty status and educational attainment could have an effect on drug overdose and subsequent death.[6-10] One recent study investigated the existence of a social gradient in fatal drug overdose cases related to non-prescribed opioids.[11] The researchers found that the mortality rate of opioid and cocaine users from the lowest socioeconomic group was 9.88 times higher than that of their peers of the highest socioeconomic group. One study estimating associations between socioeconomic indicators and opioid-related deaths for Orange County, California found that males, persons aged 45-54, and people identifying as Caucasian had the highest rate of opioid mortality.[12] Additionally, the highest 
medRxiv preprint doi: https://doi.org/10.1101/19005140; this version posted September 5, 2019. The copyright holder for this preprint (which was not certified by peer review) is the author/funder, who has granted medRxiv a license to display the preprint in perpetuity.

It is made available under a CC-BY-NC-ND 4.0 International license .

death rates were seen in homeless adults. Another recent study revealed an association between low income neighborhoods and increased risk of receiving an opioid treatment for back pain.[13] Despite the existing research on the associations between socioeconomic factors and opioidrelated mortality, all associated socioeconomic factors have not yet been fully elucidated and may vary from region to region, thus calling for more specific studies.

Recently, large-scale data sources related to opioid misuse have become publicly available, although some require Data Use Agreements (DUAs) to access. We used a large-scale vital statistic dataset from the ODH and U.S. Census datasets to perform retrospective and extensive analysis at a statewide and Census tract level. Our study focused on Ohio, as opioid overdose and abuse has become the most urgent public health issue facing Ohio. In 2017, Ohio had the second highest rate of opioid-involved overdose death in the country, at 39.2 deaths per 100,000 persons [14] compared to the national average of 14.9 per $100,000 .[1]$

The objective of this study is to reveal the socioeconomic factors of communities that are significantly associated with increased opioid overdose-related mortality rates in Ohio at the census tract level. We expect to produce useful analytic results to help government officials and healthcare providers focus their efforts to solve the opioid epidemic.

\section{METHODS}

\section{Data Description}

With the exception of the rural/urban status, which was extracted from the 2010 Census,[15] all data were obtained from the American Community Survey (ACS) for Ohio from 2010-2016.[16] As a result, all variables changed over time using the updated ACS 5-year estimates, with the exception of the percentage rural/urban status which was fixed across all study years using 2010 Census values. For the state of Ohio, we extracted overall population estimates as well as population estimates by gender, age and race. For each census tract, we extracted the percentage of the population with characteristics related to gender, age, race, ethnicity, education, marital 
medRxiv preprint doi: https://doi.org/10.1101/19005140; this version posted September 5, 2019. The copyright holder for this preprint (which was not certified by peer review) is the author/funder, who has granted medRxiv a license to display the preprint in perpetuity.

It is made available under a CC-BY-NC-ND 4.0 International license .

status, household occupancy, employment, poverty, income, health insurance, rural/urban status and housing.

All data on opioid-related deaths were extracted from ODH mortality data containing decedent information by opioid poisoning and misuse (2010-2016). We were approved to access limited and identifiable data, completed the DUA, and de-identified decedent data. Access and use of the data was approved by the ODH IRB. From the entire set of vital records containing information on all deaths in Ohio, we selected only opioid-related records. We considered a death opioidrelated if the record had a positive value for any of the following nine indicators: Methadone, opiates, prescription opiates, Fentanyl, Fentanyl and Analogues, Carfentanil, designer opioids, commonly prescribed opioids, and/or other opioids. Then, we chose records for analysis which contained positive values for "Opioid Related Death," "Unintended Death," "Undetermined death," and "Drug Poisoning Injury Mechanism."

\section{Analysis}

We explored trends in the opioid-related death rate, calculated as the number of opioid deaths per 10,000 persons, between 2010 and 2016 by gender, age and race. We then compared the distributions of gender, age and race among the entire Ohio population to the distributions among those opioid fatalities. Chi-square goodness of fit tests were used to determine whether the distribution of characteristics among the opioid fatalities were different than those of the Ohio population.

We then aimed to explore the relationship between the extracted census tract characteristics and the opioid-related death rate among Ohio census tracts using regression analysis. For the purposes of the regression analysis, those census tracts with a population of zero were removed. We first calculated descriptive statistics (mean and standard deviation) for all of the variables considered for the regression analysis. We then explored the unadjusted relationships between each variable and the opioid-related death rate using Poisson regression with the log of the 
medRxiv preprint doi: https://doi.org/10.1101/19005140; this version posted September 5, 2019. The copyright holder for this preprint (which was not certified by peer review) is the author/funder, who has granted medRxiv a license to display the preprint in perpetuity.

It is made available under a CC-BY-NC-ND 4.0 International license .

census tract population serving as the offset. We used a deviance adjustment to the scale parameter for the unadjusted analysis due to slight overdispersion. Because the variables selected for the regression analysis displayed a high degree of multicollinearity, we reduced the number of variables for consideration in the multivariable regression model based on variance inflation factors $(\mathrm{VIF})<5$. To explore the relative importance of each category, multivariable Poisson regression models with no adjustment to the scale parameter were fit using stepwise model building and an alpha level of 0.05 . The final set of variables used in the multivariable model building are listed in Table 3. The regression analysis was performed separately for each year, since we suspected that relationships between the census tract characteristics and the opioid-related death rates may differ over time. The results for each year are presented overall, as well as separately for mostly urban and mostly rural census tracts, because we also suspected that the rural/urban classification would affect the factors associated with the opioid-related death rates.

Results are reported as the rate ratio (RR) and $95 \%$ confidence interval (95\% CI) and can be understood as the relative risk of death by opioid overdose in the given group, with a confidence interval encompassing the value of 1 signifying nonsignificance.

We used SAS version 9.4 (SAS Institute) to conduct the analyses.

\section{RESULTS}

Opioid-related death rates have increased over time in Ohio during 2010-2016. Rates are highest among males as compared to females (Figure 1A), among persons aged 25-44 years followed by 45-54 years (Figure 1B), and among whites (Figure 1C).

These same groups also constitute a higher proportion of opioid deaths compared to that of the general Ohio population, with a higher percentage of males (67.2\% vs.48.9\%, Figure 2A), individuals $25-44$ years and $45-54$ years (52.6\% vs. $25.1 \%$ and $24.3 \%$ vs. $14.6 \%$, respectively, Figure 2B), and whites (90.7\% vs. 82.8\%, Figure 2C). 
In general, the distributions of the census tract characteristics appear similar over time (Supplementary Table 1). On average, the census tract populations have a larger percentage of females, persons aged 25-44 years, whites, persons with at least a high school degree, and persons not married. On average, almost half of households have a single head, about a quarter are living under $150 \%$ of the poverty level, and about $80 \%$ live in predominately urban areas. The associations between the census tract characteristics and the opioid-related death rate varied across the years, but certain patterns did emerge both prior to adjustment (Supplementary Table 2) and after adjustment for the variables in the multivariable models (Table 1).

After adjustment, an increase in the percentage of the population 54 years or younger was associated with an increase in the death rate. Having an increase in the percentage of the population 65 years and older was associated with a decrease in the death rate. Census tracts with higher opioid-related death rates were also associated with a greater percentage of whites, divorced/separated people, education levels up to high school completion, people living in urban areas, male headed households with no female present, head of households living alone, and vacant housing units. In 2016, for a 5\% increase in the percentage of 45-54 year olds, the opioidrelated death rate was $1.19(95 \% \mathrm{CI}=1.12-1.26)$ times higher. In 2016, for a $5 \%$ increase in the percentage of whites, the opioid-related death rate was 1.04 (95\% CI=1.03-1.05) times higher; for a $5 \%$ increase in the percentage without a high school diploma, 1.08 (95\% CI=1.04-1.11); for a 5\% increase in the percentage with only a high school diploma, 1.03 (95\% CI=1.01-1.06); for a $5 \%$ increase in the percentage in urban areas, $1.04(95 \% \mathrm{CI}=1.03-1.05)$; for a $5 \%$ increase in the percentage of male headed households with no female present, 1.10 (95\% CI=1.03-1.18); for a $5 \%$ increase in the percentage of head of households living alone, 1.08 (95\% CI=1.061.10); and for a 5\% increase in the percentage of vacant housing units, 1.07 (95\% CI=1.04-1.10). A higher median house value was associated with a lower opioid-related death rate; in 2016, the 
medRxiv preprint doi: https://doi.org/10.1101/19005140; this version posted September 5, 2019. The copyright holder for this preprint (which was not certified by peer review) is the author/funder, who has granted medRxiv a license to display the preprint in perpetuity.

It is made available under a CC-BY-NC-ND 4.0 International license .

death rate was reduced by a factor of $0.97(95 \% \mathrm{CI}=0.96-0.97)$ for every $\$ 10,000$ increase in the median house value. 
Table 1. Adjusted associations between census tract characteristics and opioid-related death rates, Ohio, 2010-2016.

\begin{tabular}{|c|c|c|c|c|c|c|c|}
\hline Characteristics $\$$ & $\begin{array}{c}2010 \\
R^{*}(95 \% \mathrm{Cl}) \\
\end{array}$ & $\begin{array}{c}2011 \\
\operatorname{RR}^{*}(95 \% \mathrm{Cl}) \\
\end{array}$ & $\begin{array}{c}2012 \\
\operatorname{RR}^{*}(95 \% \mathrm{Cl})\end{array}$ & $\begin{array}{c}2013 \\
\operatorname{RR}^{*}(95 \% \mathrm{Cl}) \\
\end{array}$ & $\begin{array}{c}2014 \\
\operatorname{RR}^{*}(95 \% \mathrm{Cl}) \\
\end{array}$ & $\begin{array}{c}2015 \\
R^{*}(95 \% \mathrm{Cl}) \\
\end{array}$ & $\begin{array}{c}2016 \\
\operatorname{RR}^{*}(95 \% \mathrm{Cl}) \\
\end{array}$ \\
\hline \multicolumn{8}{|l|}{ Gender } \\
\hline$\%$ Male & & & & & & & $0.95(0.90-0.99)$ \\
\hline \multicolumn{8}{|l|}{ Age } \\
\hline$\%$ Age $<5$ years & & $1.25(1.10-1.43)$ & & & & $1.13(1.04-1.23)$ & \\
\hline$\%$ Age $25-44$ years & & & & $1.12(1.07-1.17)$ & & & \\
\hline$\%$ Age $45-54$ years & & $1.22(1.10-1.34)$ & & $1.21(1.11-1.31)$ & $1.13(1.05-1.22)$ & $1.13(1.05-1.21)$ & $1.19(1.12-1.26)$ \\
\hline$\%$ Age $55-64$ years & & & & & & & $1.25(1.17-1.33)$ \\
\hline$\%$ Age $65-74$ years & & & & & & & $0.91(0.84-0.99)$ \\
\hline$\%$ Age $\geq 75$ years & $0.85(0.78-0.94)$ & $0.84(0.75-0.93)$ & $0.74(0.65-0.84)$ & & $0.88(0.82-0.95)$ & & $0.86(0.81-0.92)$ \\
\hline \multicolumn{8}{|l|}{ Race/Ethnicity } \\
\hline \% One Race - White & $1.04(1.02-1.05)$ & $1.04(1.02-1.05)$ & $1.05(1.03-1.06)$ & $1.04(1.03-1.05)$ & $1.06(1.05-1.08)$ & $1.05(1.04-1.06)$ & $1.04(1.03-1.05)$ \\
\hline \% Multiracial & & & & & $1.12(1.02-1.23)$ & & \\
\hline \% Hispanic & & & $1.05(1.00-1.09)$ & $1.04(0.99-1.08)$ & & $0.96(0.93-0.99)$ & \\
\hline \multicolumn{8}{|l|}{ Education } \\
\hline $\begin{array}{l}\text { \% Less than high } \\
\text { school graduate }\end{array}$ & $1.10(1.05-1.15)$ & $1.18(1.13-1.23)$ & $1.15(1.10-1.19)$ & $1.12(1.07-1.16)$ & $1.07(1.03-1.12)$ & $1.10(1.06-1.14)$ & $1.08(1.04-1.11)$ \\
\hline $\begin{array}{l}\text { \% High school } \\
\text { graduate } \\
\text { Marital Status }\end{array}$ & $1.07(1.03-1.11)$ & & & $1.07(1.03-1.10)$ & $1.04(1.01-1.08)$ & $1.06(1.03-1.09)$ & $1.03(1.01-1.06)$ \\
\hline \% Divorced/separated & $1.17(1.08-1.26)$ & & $1.22(1.15-1.30)$ & $1.11(1.03-1.19)$ & & $1.13(1.07-1.19)$ & \\
\hline \% Widowed & & & $1.21(1.04-1.38)$ & & & $0.82(0.76-0.89)$ & \\
\hline \multicolumn{8}{|l|}{ Rural or Urban Area } \\
\hline \% Urban & $1.04(1.03-1.05)$ & $1.03(1.01-1.04)$ & 1.05 (1.04-1.06) & $1.03(1.02-1.04)$ & $1.04(1.03-1.05)$ & $1.04(1.03-1.05)$ & $1.04(1.03-1.05)$ \\
\hline \multicolumn{8}{|l|}{ Household Occupancy } \\
\hline $\begin{array}{l}\text { \% Male head of } \\
\text { household-no female } \\
\text { present }\end{array}$ & $1.22(1.09-1.37)$ & $1.14(1.02-1.28)$ & & & & $1.08(1.00-1.17)$ & $1.10(1.03-1.18)$ \\
\hline $\begin{array}{l}\% \text { Head of household } \\
\text { living alone }\end{array}$ & $1.08(1.04-1.13)$ & $1.12(1.08-1.16)$ & & $1.06(1.03-1.09)$ & $1.08(1.05-1.11)$ & $1.08(1.05-1.11)$ & $1.08(1.06-1.10)$ \\
\hline
\end{tabular}

Employment 


\begin{tabular}{|c|c|c|c|c|c|c|c|}
\hline Characteristics $\$$ & $\begin{array}{c}2010 \\
\operatorname{RR}^{*}(95 \% \mathrm{Cl}) \\
\end{array}$ & $\begin{array}{c}2011 \\
\operatorname{RR}^{*}(95 \% \mathrm{Cl}) \\
\end{array}$ & $\begin{array}{c}2012 \\
\operatorname{RR}^{*}(95 \% \mathrm{Cl}) \\
\end{array}$ & $\begin{array}{c}2013 \\
\operatorname{RR}^{*}(95 \% \mathrm{Cl}) \\
\end{array}$ & $\begin{array}{c}2014 \\
\operatorname{RR}^{*}(95 \% \mathrm{Cl}) \\
\end{array}$ & $\begin{array}{c}2015 \\
\operatorname{RR}^{*}(95 \% \mathrm{Cl}) \\
\end{array}$ & $\begin{array}{c}2016 \\
\operatorname{RR}^{*}(95 \% \mathrm{Cl}) \\
\end{array}$ \\
\hline $\begin{array}{l}\text { \% Civilian labor force } \\
\text { unemployed } \\
\text { Income \& Assistance }\end{array}$ & $0.90(0.80-1.00)$ & & & & $1.13(1.04-1.22)$ & & $1.09(1.02-1.17)$ \\
\hline $\begin{array}{l}\text { \% With cash public } \\
\text { assistance income }\end{array}$ & & $0.89(0.80-1.00)$ & & $1.12(1.04-1.21)$ & & & $1.07(1.02-1.13)$ \\
\hline \multicolumn{8}{|l|}{ Health Insurance } \\
\hline $\begin{array}{l}\text { \% Without health } \\
\text { insurance } \\
\text { Housing }\end{array}$ & & & & & $1.07(1.02-1.12)$ & & $1.07(1.03-1.12)$ \\
\hline $\begin{array}{l}\% \text { Vacant housing } \\
\text { units }\end{array}$ & $1.07(1.02-1.12)$ & & $1.05(1.00-1.09)$ & $1.10(1.06-1.14)$ & $1.13(1.10-1.17)$ & $1.11(1.08-1.14)$ & $1.07(1.04-1.10)$ \\
\hline $\begin{array}{l}\%>1 \text { occupants per } \\
\text { room }\end{array}$ & & & & & & $1.17(1.04-1.32)$ & \\
\hline $\begin{array}{l}\% \text { Lacking complete } \\
\text { kitchen facilities }\end{array}$ & $0.77(0.62-0.98)$ & & & & & & \\
\hline Median house value & & $0.97(0.95-0.98)$ & & & $0.99(0.97-1.00)$ & $0.98(0.97-1.00)$ & $0.97(0.96-0.98)$ \\
\hline
\end{tabular}

$\mathrm{RR}=$ Rate ratio; $\mathrm{Cl}=$ Confidence interval.

*RR are for a $5 \%$ increase in all percentages and a $\$ 10,000$ increase in median house value.

\$Variables listed in Table 2 that were not considered for the adjusted multivariable analysis due to multicollinearity include: \% female, \% age $18-24, \%$ one race - black, \% one race other, \% some college or associates degree, $\%$ at least a bachelor's degree, $\%$ married, $\%$ never married, $\%$ female head of household with no male present, \% unemployment, \% living $<150 \%$ of poverty level, \% living $\geq 150 \%$ of poverty level, median household income, $\%$ food stamps or SNAP benefits, \% with health insurance, \% owner occupied housing, and \% with $\leq 1$ occupant per room. Variables listed in Table 2 that were considered for the adjusted multivariable analysis but were not included in any of the models due to non-significance include $\%$ age $5-17, \%$ labor force in armed forces, \% lacking plumbing, \%without a vehicle, and \% with $>1$ occupant per room. 
Census tracts that were predominantly rural had, on average, a higher percentages of males, whites, high school graduates (versus at least a bachelor's degree), married persons, and owneroccupied homes, as well as higher median household incomes than compared to predominantly urban census tracts (Supplementary Tables 3A-3B). Predominantly rural census tracts also had, on average, a lower percentage of female headed households with no male present, households headed by persons living alone, unemployed, households below $150 \%$ of the poverty level, and households receiving public assistance or using food stamps. We found that the models of the overall population characteristics against the opioid-related death rates showed few significant associations with the predominantly rural areas prior to adjustment, while the results for the predominantly urban areas more closely reflected the overall results (Supplementary Tables 4A4B). For the rural census tracts after adjustment, few characteristics were significantly associated with changes in the opioid-related death rates. The only factors showing a rather consistent association over time were the percentage of the population aged 25-54 and the percentage divorced/separated, with both resulting in an increase in the death rate for a $5 \%$ increase in the characteristic (Table 2A). However, the adjusted results for the urban census tracts were similar to the overall adjusted results (Table 2B). 
Table 2A. Adjusted associations between census tract characteristics and opioid-related death rates, predominantly rural tracts only, Ohio, 20102016.

\begin{tabular}{|c|c|c|c|c|c|c|c|}
\hline Characteristics\$ & $\begin{array}{c}2010 \\
\operatorname{RR}^{*}(95 \% \mathrm{Cl})\end{array}$ & $\begin{array}{c}2011 \\
\operatorname{RR}^{*}(95 \% \mathrm{Cl})\end{array}$ & $\begin{array}{c}2012 \\
\operatorname{RR}^{*}(95 \% \mathrm{Cl})\end{array}$ & $\begin{array}{c}2013 \\
\operatorname{RR}^{*}(95 \% \mathrm{Cl})\end{array}$ & $\begin{array}{c}2014 \\
\operatorname{RR}^{*}(95 \% \mathrm{Cl})\end{array}$ & $\begin{array}{c}2015 \\
\operatorname{RR}^{*}(95 \% \mathrm{Cl})\end{array}$ & $\begin{array}{c}2016 \\
\operatorname{RR}^{*}(95 \% \mathrm{Cl})\end{array}$ \\
\hline \multicolumn{8}{|l|}{ Age } \\
\hline \% Age 5-17 years & & & & $0.82(0.68-0.99)$ & & & \\
\hline$\%$ Age $45-54$ years & & & & & & $1.43(1.15-1.78)$ & $1.22(1.01-1.47)$ \\
\hline$\%$ Age $55-64$ years & & & $1.58(1.17-2.14)$ & & $1.35(1.09-1.66)$ & $1.26(1.04-1.52)$ & $1.24(1.06-1.46)$ \\
\hline$\%$ Age $65-74$ years & & & $0.62(0.40-0.96)$ & & & & \\
\hline \multicolumn{8}{|l|}{ Race/Ethnicity } \\
\hline$\%$ Multiracial & & & & & $1.59(1.03-2.45)$ & & \\
\hline \% Hispanic & $0.32(0.15-0.69)$ & & & & & & \\
\hline \multicolumn{8}{|l|}{ Marital Status } \\
\hline $\begin{array}{l}\% \\
\text { Divorced/separated }\end{array}$ & $1.39(1.08-1.79)$ & $1.48(1.19-1.83)$ & $1.29(1.02-1.62)$ & $1.40(1.17-1.67)$ & $1.33(1.13-1.57)$ & $1.33(1.13-1.55)$ & $1.22(1.06-1.41)$ \\
\hline \multicolumn{8}{|l|}{ Employment } \\
\hline $\begin{array}{l}\text { \% Civilian labor force } \\
\text { unemployed } \\
\text { Income \& Assistance }\end{array}$ & & & $1.57(0.15-2.34)$ & & & & $1.41(1.07-1.88)$ \\
\hline $\begin{array}{l}\% \text { With cash public } \\
\text { assistance income }\end{array}$ & & & & & & $1.76(1.27-2.45)$ & \\
\hline \multicolumn{8}{|l|}{ Housing } \\
\hline$\%$ Without a vehicle & $0.68(0.48-0.97)$ & & & & & & \\
\hline $\begin{array}{l}\% \text { Lacking complete } \\
\text { plumbing facilities }\end{array}$ & & & $0.37(0.14-0.98)$ & & & & \\
\hline
\end{tabular}

$\mathrm{RR}=$ Rate ratio; $\mathrm{Cl}=$ Confidence interval.

${ }^{*}$ RR are for a $5 \%$ increase in all percentages and a $\$ 10,000$ increase in median house value.

\$Variables listed in Table 2 that were not considered for the adjusted multivariable analysis due to multicollinearity include: \% female, \% age 18-24, \% one race - black, \% one race other, \% some college or associates degree, \% at least a bachelor's degree, \% married, \% never married, \% female head of household with no male present, \% unemployment, \% living 


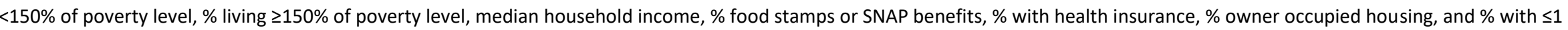

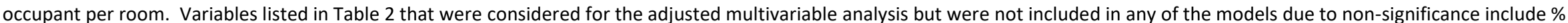
age $<5$, \% age $25-44, \%$ age $\geq 75$, \% one race white, $\%$ less than high school graduate, $\%$ high school graduate, $\%$ widowed, $\%$ male head of household - no female present, $\%$ head of household living alone, \% without health insurance, \% lacking plumbing, \%vacant housing units, \%without a complete kitchen, \% with >1 occupant per room, and median house value. 
Table 2B. Adjusted associations between census tract characteristics and opioid-related death rates, predominantly urban tracts only, Ohio, 2010-2016.

\begin{tabular}{|c|c|c|c|c|c|c|c|}
\hline Characteristics\$ & $\begin{array}{c}2010 \\
\operatorname{RR}^{*}(95 \% \mathrm{Cl})\end{array}$ & $\begin{array}{c}2011 \\
\operatorname{RR}^{*}(95 \% \mathrm{Cl})\end{array}$ & $\begin{array}{c}2012 \\
\operatorname{RR}^{*}(95 \% \mathrm{Cl})\end{array}$ & $\begin{array}{c}2013 \\
\operatorname{RR}^{*}(95 \% \mathrm{Cl})\end{array}$ & $\begin{array}{c}2014 \\
\operatorname{RR}^{*}(95 \% \mathrm{Cl})\end{array}$ & $\begin{array}{c}2015 \\
\operatorname{RR}^{*}(95 \% \mathrm{Cl})\end{array}$ & $\begin{array}{c}2016 \\
\operatorname{RR}^{*}(95 \% \mathrm{Cl})\end{array}$ \\
\hline \multicolumn{8}{|l|}{ Gender } \\
\hline$\%$ Male & & & & & & & $0.94(0.89-0.99)$ \\
\hline \multicolumn{8}{|l|}{ Age } \\
\hline$\%$ Age $<5$ years & & $1.33(1.16-1.52)$ & & & $1.15(1.04-1.27)$ & $1.15(1.06-1.25)$ & \\
\hline$\%$ Age $25-44$ years & & & $1.10(1.02-1.19)$ & 1.13 (1.07-1.19) & & & \\
\hline$\%$ Age $45-54$ years & & $1.18(1.06-1.31)$ & & 1.17 (1.08-1.28) & $1.13(1.04-1.22)$ & & $1.16(1.09-1.23)$ \\
\hline$\%$ Age $55-64$ years & 0.89 (0.79-0.99) & & & & & & $1.22(1.14-1.30)$ \\
\hline$\%$ Age $65-74$ years & & & & & $0.88(0.80-0.97)$ & & $0.91(0.84-0.99)$ \\
\hline$\%$ Age $\geq 75$ years & $0.90(0.80-0.97)$ & $0.85(0.77-0.95)$ & $0.83(0.75-0.91)$ & & & & $0.88(0.83-0.94)$ \\
\hline \multicolumn{8}{|l|}{ Race/Ethnicity } \\
\hline \% One Race - White & $1.03(1.02-1.05)$ & $1.03(1.02-1.05)$ & 1.05 (1.04-1.07) & $1.04(1.03-1.06)$ & $1.06(1.05-1.08)$ & 1.05 (1.04-1.06) & $1.04(1.03-1.05)$ \\
\hline \% Hispanic & & & & $1.04(1.00-1.08)$ & & $0.95(0.91-0.98)$ & \\
\hline \multicolumn{8}{|l|}{ Education } \\
\hline $\begin{array}{l}\% \text { Less than high } \\
\text { school graduate }\end{array}$ & $1.11(1.05-1.16)$ & $1.25(1.19-1.31)$ & $1.18(1.13-1.23)$ & $1.14(1.08-1.19)$ & $1.08(1.04-1.13)$ & $1.11(1.06-1.15)$ & $1.09(1.05-1.13)$ \\
\hline $\begin{array}{l}\text { \% High school } \\
\text { graduate }\end{array}$ & $1.06(1.02-1.10)$ & & & $1.06(1.03-1.10)$ & 1.05 (1.02-1.07) & $1.04(1.01-1.07)$ & \\
\hline \multicolumn{8}{|l|}{ Marital Status } \\
\hline \% Divorced/separated & $1.18(1.09-1.27)$ & & $1.11(1.04-1.19)$ & $1.09(1.02-1.17)$ & & $1.14(1.08-1.20)$ & \\
\hline \% Widowed & & & & & & $0.83(0.77-0.90)$ & \\
\hline \multicolumn{8}{|l|}{ Household Occupancy } \\
\hline $\begin{array}{l}\% \text { Male head of } \\
\text { household-no female } \\
\text { present }\end{array}$ & $1.21(1.07-1.36)$ & & & & & & $1.09(1.02-1.17)$ \\
\hline $\begin{array}{l}\% \text { Head of household } \\
\text { living alone }\end{array}$ & $1.08(1.04-1.12)$ & $1.12(1.08-1.16)$ & $1.08(1.03-1.12)$ & 1.07 (1.04-1.10) & $1.08(1.05-1.11)$ & $1.07(1.04-1.10)$ & $1.08(1.06-1.10)$ \\
\hline Employment & & & & & & & \\
\hline
\end{tabular}

\% Civilian labor force
unemployed


Health Insurance

\section{$\%$ Without health}

insurance

$1.12(1.06-1.20)$

$1.16(1.10-1.23)$

$1.11(1.05-1.17)$

$1.13(1.07-1.19)$

Housing

$\%$ Vacant housing

units

$1.06(1.01-1.12)$

$1.11(1.07-1.15) \quad 1.11(1.07-1.15)$

$1.09(1.06-1.13) \quad 1.06(1.03-1.09)$

$\%>1$ occupants per

room

1.18 (1.04-1.34)

\% Lacking complete

plumbing facilities

Median house value

$1.46(1.16-1.85)$

$1.27(1.03-1.57)$

$\mathrm{RR}=$ Rate ratio $\mathrm{Cl}=$ Confidence interval.

${ }^{*}$ RR are for a $5 \%$ increase in all percentages and a $\$ 10,000$ increase in median house value.

$\$$ Variables listed in Table 2 that were not considered for the adjusted multivariable analysis due to multicollinearity include: \% female, \% age $18-24, \%$ one race - black, \% one race - other, \% some college or associates degree, \% at least a bachelor's degree, $\%$ married, $\%$ never married, $\%$ female head of household with no male present, \%

unemployment, $\%$ living $<150 \%$ of poverty level, $\%$ living $\geq 150 \%$ of poverty level, median household income, $\%$ food stamps or SNAP benefits, $\%$ with health insurance, $\%$ owner occupied housing, and \% with $\leq 1$ occupant per room. Variables listed in Table 2 that were considered for the adjusted multivariable analysis but were not included in any of the models due to non-significance include \% age 5-17, \% multiracial, \% labor force in armed forces, \%without a vehicle, and \% without a complete kitchen. 
medRxiv preprint doi: https://doi.org/10.1101/19005140; this version posted September 5, 2019. The copyright holder for this preprint (which was not certified by peer review) is the author/funder, who has granted medRxiv a license to display the preprint in perpetuity.

It is made available under a CC-BY-NC-ND 4.0 International license .

\section{DISCUSSION}

This study focused on the socioeconomic factors of Ohio census tracts and their association with opioid-overdose related death rates from 2010 to 2016. Regression analysis was performed using mortality data from the ODH and data extracted from the ACS for the state of Ohio.

Analysis of associations between changes in census tract socioeconomic factors and opioidrelated death rates in Ohio census tracts found that an increase in the death rate was associated with an increase in the prevalence of the following census tract characteristics: percentage of the population aged 25-55, percentage of whites, percentage of educational attainment less than or equal to high school completion, percentage divorced/separated, percentage living in urban areas, percentage of male-headed households without a female present, percentage of head of households living alone, and the percentage of vacant housing units. A higher median house value was associated with a lower death rate. These findings are interesting as they reflect the increase of drug overdose deaths in urban areas compared to that of rural areas that was observed in 2017.[17] While the increase in narcotic-related death rates for rural areas surpassed that of urban areas between 1999-2004,[18] recent data shows higher death rates in urban counties.[17] Our findings are also consistent with research that found a significant association between higher numbers housing vacancies and higher rates of opioid-related death.[19]

These associations were found to hold for urban census tracts, while rural tracts did not show the same associations, except for the percentage of the population aged 25-54 and the percent that was divorced/separated. Thus, our research shows that the socioeconomic factors that predict opioid-related deaths in urban populations do not hold for rural populations. While this observation may be due to the more homogeneous makeup of rural areas or their smaller sample size, it may also indicate the changing geographical patterns of opioid abuse. Census tract level socioeconomic characteristics other than those that are presented here should be considered in 
medRxiv preprint doi: https://doi.org/10.1101/19005140; this version posted September 5, 2019. The copyright holder for this preprint (which was not certified by peer review) is the author/funder, who has granted medRxiv a license to display the preprint in perpetuity.

It is made available under a CC-BY-NC-ND 4.0 International license .

order to predict opioid abuse in rural tracts, in addition to researching which drugs are used more widely in urban versus rural areas.

Limitations of this study include the exclusion of several variables from the multivariable model building, as they exhibited multicollinearity. Additionally, the analysis is based on census-tract level data and shows associations between community characteristics and community death rates and does not explore personal risk factors for opioid-abuse related deaths. Finally, all variables except the information about rural and urban communities came from the ACS and thus were updated on an annual basis, while the rural and urban data came from the 2010 Census data and is fixed for each year analyzed.

We suggest further research to analyze these associations with population data from other states to verify if the model can be expanded beyond Ohio. Additionally, further research on the spatial patterns of opioid-related deaths is needed to explore the incidence of opioid abuse in rural versus urban locations.

\section{CONCLUSION}

The rate of opioid-related deaths has consistently increased in Ohio since 2010. The highest death rates were associated with higher percentages of whites, males, and persons aged 25-54. Our study revealed significant associations using regression analysis between population characteristics of Ohio obtained from the American Community Survey for 2010-2016 and the opioid-related death rate at the census tract level during these years. Census tracts with higher death rates also exhibited higher percentages of the census tract population with educational attainment less than or equal to high school completion, higher percentages of persons divorced/separated, higher percentages in urban areas, higher percentages of male-headed households without a female present, higher percentages with the head of household living alone, and higher percentages of vacant housing units. These patterns found in the overall population did not fit predominately rural populations, but results for predominately urban populations were 
similar to those of Ohio's overall population. Future studies should explore these patterns in other states as well as analyze the geographic pattern of opioid misuse to better understand the divergent patterns of opioid use in urban versus rural areas. Our research contributes to greater understanding of predictors and patterns of opioid abuse, and will aid law enforcement agents, emergency health services, and healthcare workers to combat the opioid crisis more effectively.

\section{ACKNOWLEDGMENTS}

The authors would like to acknowledge Jesse Schold and Megan Snair of the Center for Populations Health Research of the Lerner Research Institute for their collaboration, Nabhonil Kar for his assistance on the manuscript, and the Ohio Department of Health for access to vital statistics data.

\section{Funding Statement}

This research received no specific grant from any funding agency in the public, commercial or not-for-profit sectors.

\section{Competing Interest Statement}

None declared.

\section{Contributorship Statement}

Conception or design of the work: GA, THH,

Data analysis and interpretation: CP, SC, JRC, RL, TC, AS

Drafting the article: CP, SC, RL, AS, JRC, TC, GA, THH

Critical revision of the article: CP, SC, RL, AS, JRC, TC, GA, THH

Final approval of the version to be published: GA, THH

\section{REFERENCES}

1 Scholl L, Seth P, Karisa M, et al. Drug and Opioid-Involved Overdose Deaths - United States, 2013-2017. MMWR Morb Mortal Wkly Rep 2019;67:1419-27. DOI: http://dx.doi.org/10.15585/mmwr.mm675152e1 
medRxiv preprint doi: https://doi.org/10.1101/19005140; this version posted September 5, 2019. The copyright holder for this preprint (which was not certified by peer review) is the author/funder, who has granted medRxiv a license to display the preprint in perpetuity.

It is made available under a CC-BY-NC-ND 4.0 International license .

2 U.S. Department of Health and Human Services. What is the U.S. Opioid Epidemic? https://www.hhs.gov/opioids/about-the-epidemic/index.html (accessed August 2019).

3 Centers for Disease Control and Prevention. 2018 Annual Surveillance Report of Drug-Related Risks and Outcomes - United States. Surveillance Special Report. Centers for Disease Control and Prevention, U.S. Department of Health and Human Services. Published August 31, 2018. https://www.cdc.gov/drugoverdose/pdf/pubs/2018-cdc-drugsurveillance-report.pdf (accessed August 2019).

4 Rudd RA, Seth P, David F, et al. Increases in Drug and Opioid-Involved Overdose Deaths United States, 2010-2015. MMWR Morb Mortal Wkly Rep 2016;65:1445-52.

5 United Nations Office on Drugs and Crime. World Drug Report 2019. https://wdr.unodc.org/wdr2019/ (accessed August 2019).

6 Arias LC, Borrell C. [Mortality inequalities according to education in the city of Barcelona.] Med Clin (Barc) 1998;110:161-6.

7 Farrell M, Neeleman J, Griffiths P, et al. Suicide and overdose among opiate addicts. Addiction 1996;91:321-3.

8 Marzuk PM, Tardiff K, Leon AC, et al. Poverty and fatal accidental drug overdoses of cocaine and opiates in New York City: an ecological study. Am J Drug Alcohol Abuse 1997;23:221-8.

9 Jones R, Gruer L, Gilchrist G, et al. Recent contact with health and social services by drug misusers in Glasgow who died of a fatal overdose in 1999. Addiction 2002;97:1517-22.

10 Origer A, Le Bihan E, Baumann M. Social and economic inequalities in fatal opioid and cocaine related overdoses in Luxembourg: A case-control study. Int J Drug Policy 2014;25:911-5.

11 Origer A, Le Bihan E, Baumann M. A social gradient in fatal opioids and cocaine related overdoses? PLoS One 2015;10:e0125568.

12 Marshall JR, Gassner SF, Anderson CL, et al. Socioeconomic and geographical disparities in prescription and illicit opioid-related overdose deaths in Orange County, California, from 2010-2014. Subst Abus 2018;40:1-7.

13 Gebauer S, Salas J, Scherrer JF. Neighborhood Socioeconomic Status and Receipt of Opioid Medication for New Back Pain Diagnosis. J Am Board Fam Med 2017;30:775-83.

14 National Institute on Drug Abuse. Opioid Summaries by State. Revised May 2019. https://www.drugabuse.gov/drugs-abuse/opioids/opioid-summaries-by-state (accessed August 2019). 
15. U.S. Census Bureau 2010). Retrieved from https://data.census.gov/cedsci/?intcmp=aff_cedsci_banner.

16 U.S. Census Bureau (2010). American Community Survey. Retrieved from https://www.census.gov/programs-surveys/acs/data.html.

17 Hedegaard H, Minino AM, Warner M. Urban-rural Differences in Drug Overdose Death Rates, by Sex, Age and Type of Drugs Involved, 2017. NCHS Data Brief 2019;345.

18 Paulozzi LJ, Xi Y. Recent changes in drug poisoning mortality in the United States by urbanrural status and by drug type. Pharmacoepidemiol Drug Saf 2008;17:997-1005.

19 Linton SL, Jennings JM, Latkin CA, et al. Application of space-time scan statistics to describe geographic and temporal clustering of visible drug activity. J Urban Health 2014;91:940-56. 


\section{Figures 1A-1C}

Figure 1A.

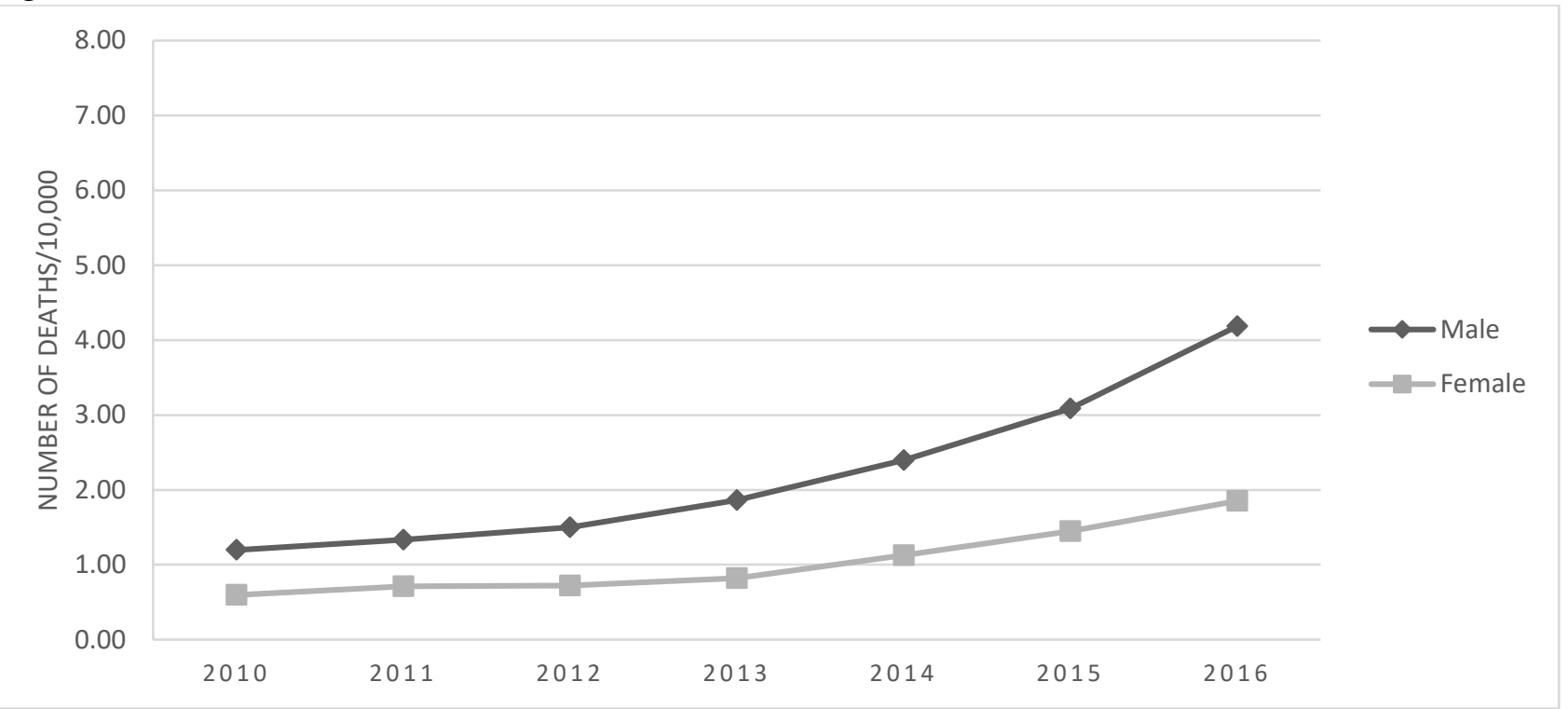

Trends in the opioid-related death rate in Ohio by gender, 2010-2016.

Figure 1B.

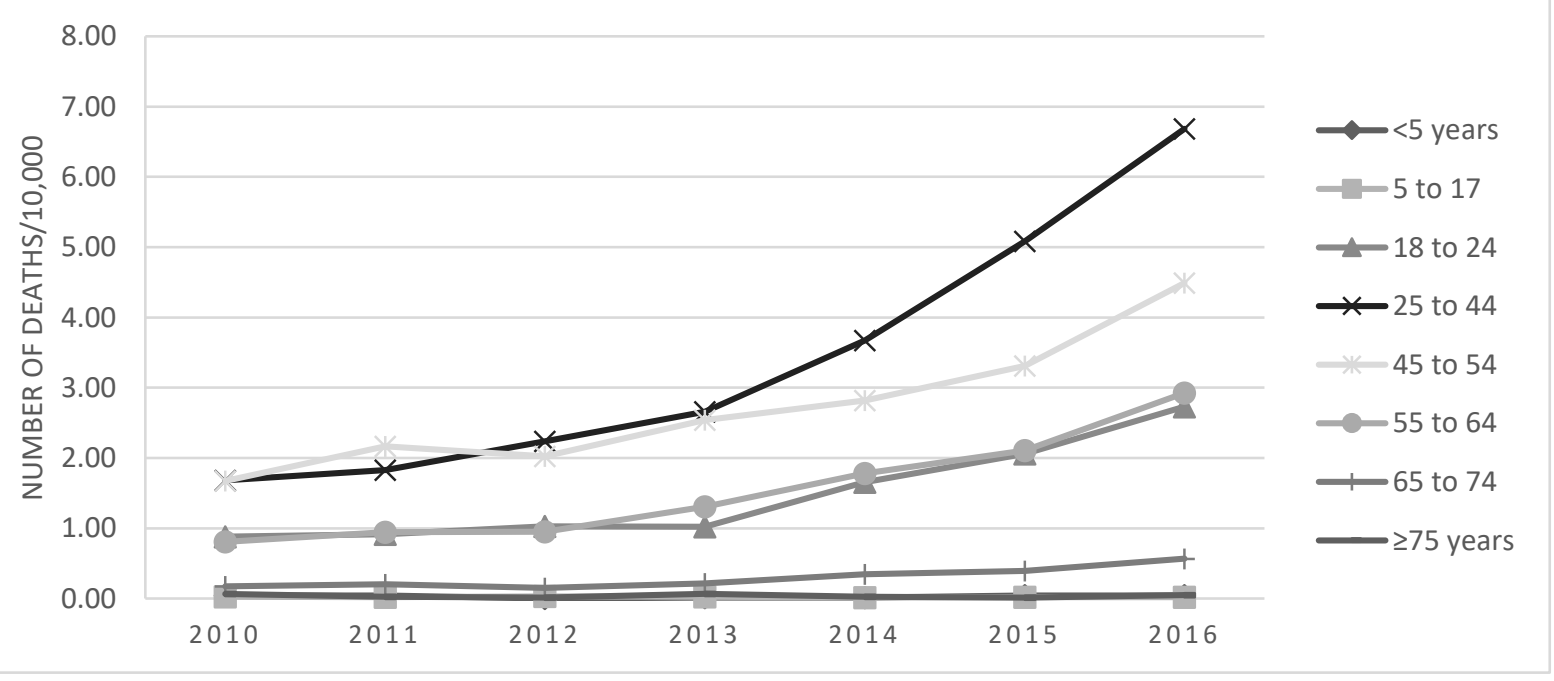


Trends in the opioid-related death rate in Ohio by age group, 2010-2016.

Figure 1C.

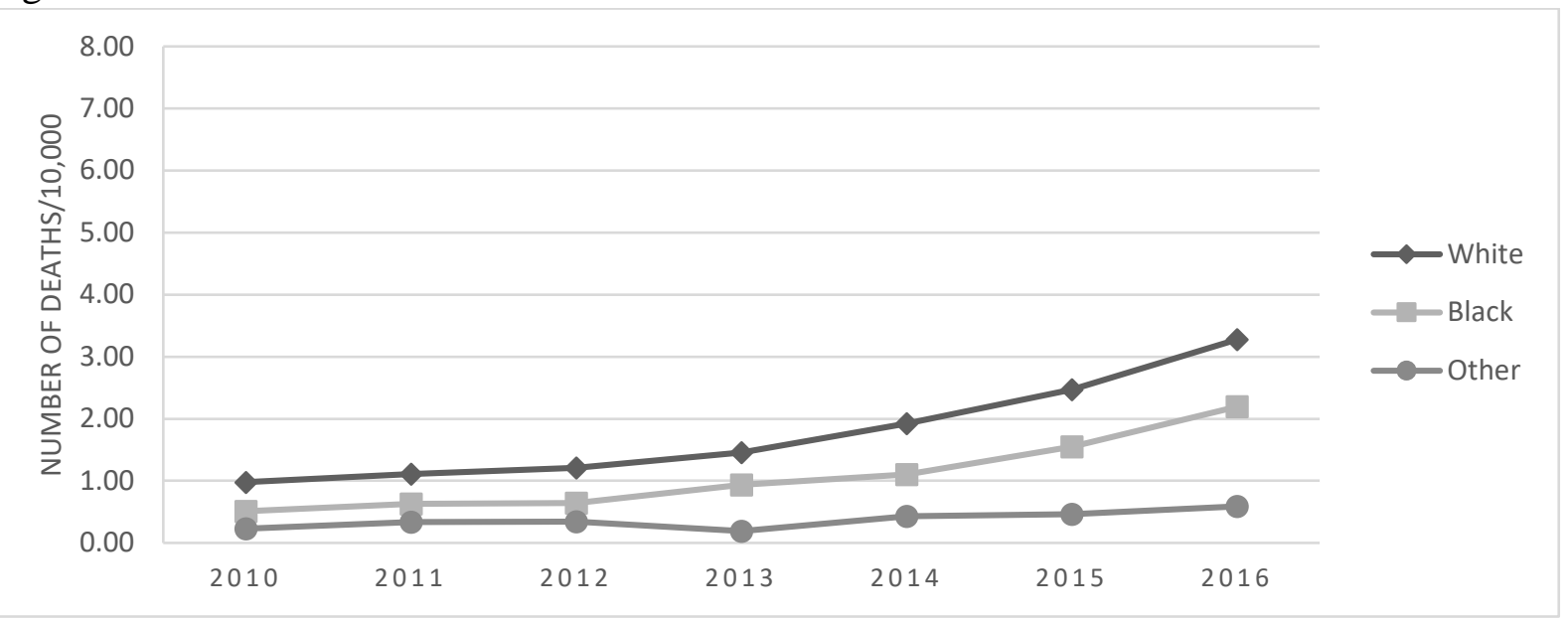

Trends in the opioid-related death rate in Ohio by race, 2010-2016.

\section{Figures 2A-2C}

Figure 2A.

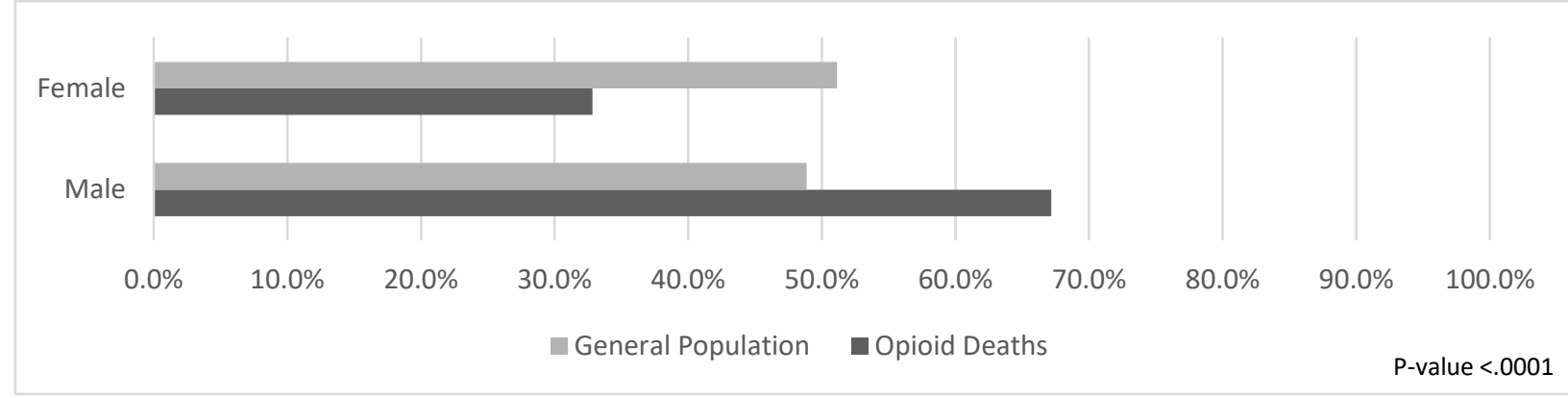

Distribution of gender among the population and among opioid fatalities in Ohio, 2010-2016. (Results combined across years.)

Figure 2B. 


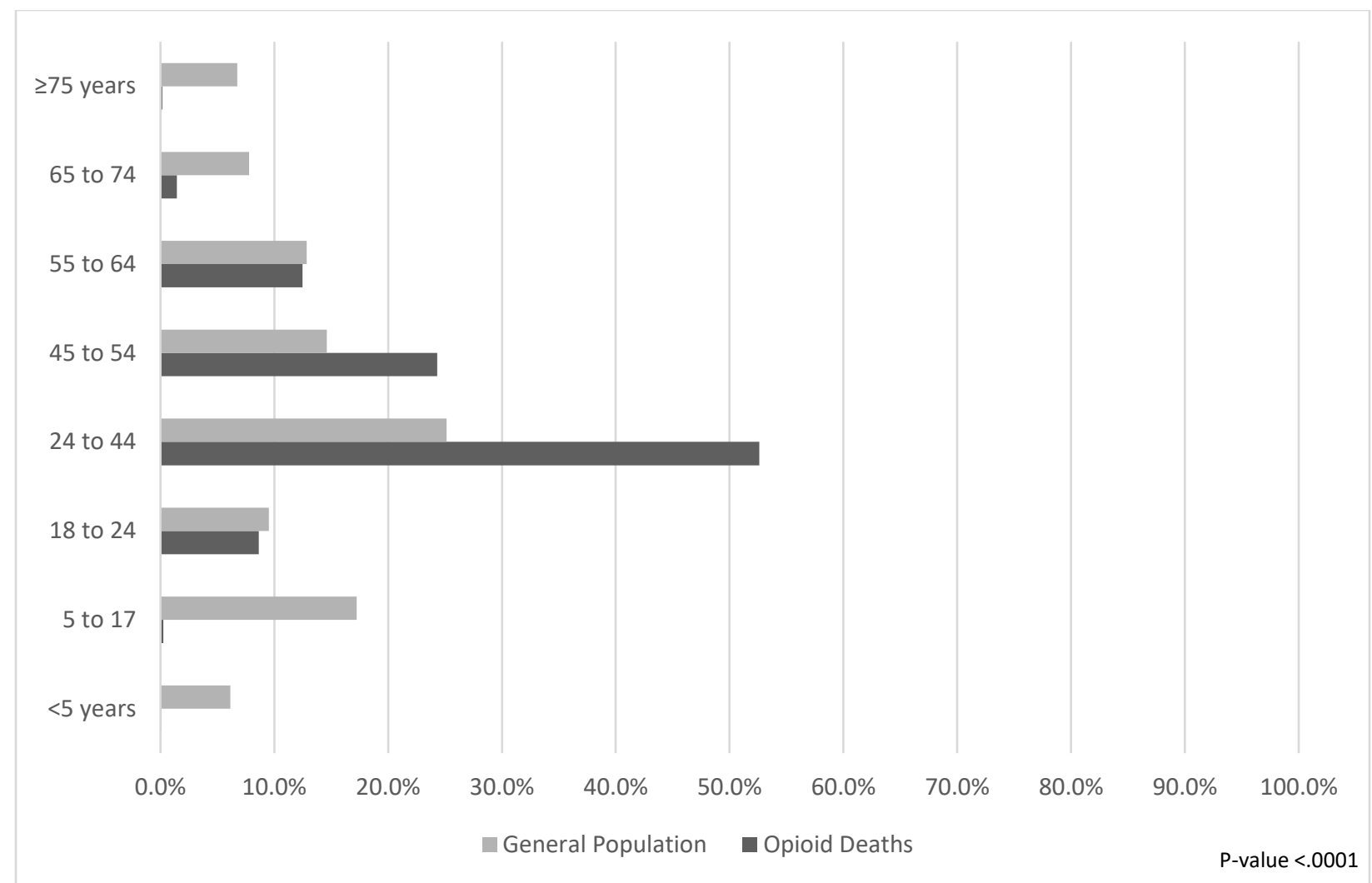

Distribution of age among the population and among opioid fatalities in Ohio, 2010-2016. (Results combined across years.)

Figure 2C.

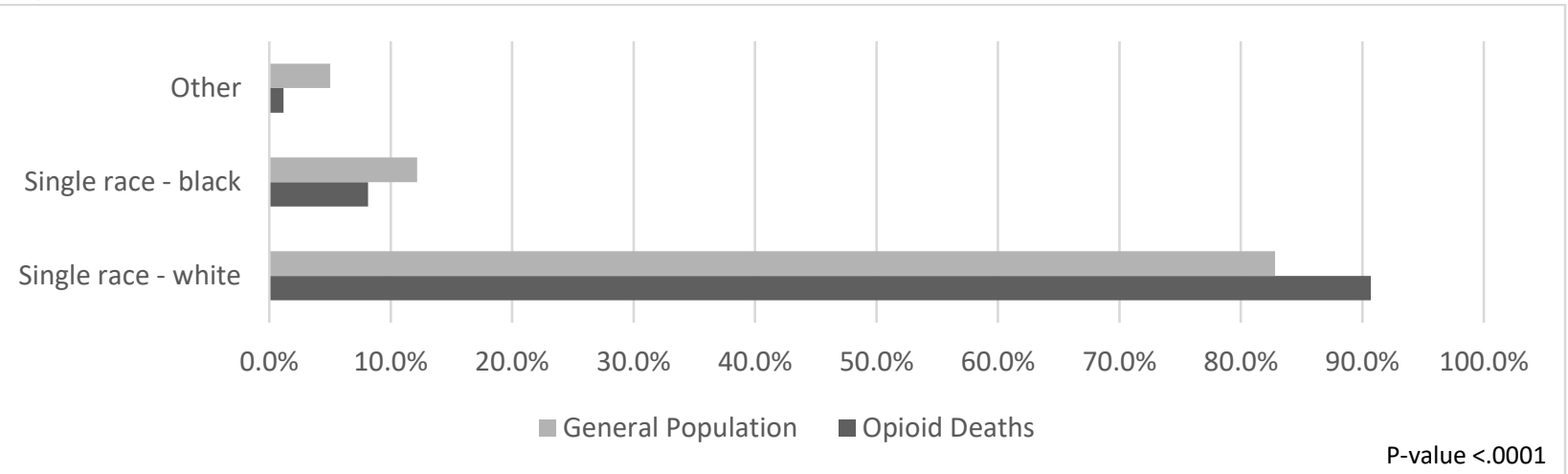

Distribution of race among the population and among opioid fatalities in Ohio, 2010-2016. (Results combined across years.) 